\title{
Primary hepatic actinomycosis mimicking a tumor (inflammatory pseudotumor): Case report and literature review
}

\author{
Ayşe Batirel', Ferhat Arslan², Sevinç Hallaç Keser ${ }^{3}$, Hasan Fehmi Kücük', Dilek Yavuzer ${ }^{3}$, Oğuz Karabay ${ }^{5}$, \\ Serdar Özer ${ }^{1}$ \\ ${ }^{1}$ Kartal Dr. Lutfi Kirdar Education and Research Hospital, Department of Infectious Diseases and Clinical Microbiology, \\ Istanbul, Turkey \\ ${ }^{2}$ Istanbul Medipol University, Department of Infectious Diseases, Istanbul, Turkey \\ ${ }^{3}$ Kartal Dr. Lutfi Kirdar Education and Research Hospital, Department of Pathology, Istanbul, Turkey \\ ${ }^{4}$ Kartal Dr. Lutfi Kirdar Education and Research Hospital, Department of General Surgery, Istanbul, Turkey \\ ${ }^{5}$ Sakarya University, Medical Faculty, Department of Infectious Diseases and Clinical Microbiology, Sakarya, Turkey
}

\begin{abstract}
Actinomycosis often manifests with abscesses in the cervicofacial region. Hepatic involvement occurs usually secondary to an intraabdominal infection. "Isolated or primary hepatic actinomycosis (PHA) defines actinomycosis in which the source of infection cannot be demonstrated elsewhere. Herein, we aimed to highlight hepatic actinomycosis in the differential diagnosis of hepatic mass lesions, and also its occurrence even in patients without underlying risk factors. A 24-year-old man, who presented with epigastric and right-upper-quadrant abdominal pain, fever, weight loss, and had a tumor-like mass in the liver was admitted to our hospital. He had no predisposing risk factors or comorbidities. We reviewed all the cases with PHA, who had no predisposing risk factors, in English medical literature from 1993 to 2014. Actinomycotic hepatic pseudotumors should be considered in the differential diagnosis of solitary liver lesions even in patients without any predisposing factors. Multi-disciplinary approach is important in the diagnosis and management. J Microbiol Infect Dis 2015;5(2): 79-84
\end{abstract}

Key words: Actinomycosis, Actinomyces spp, inflammatory pseudotumor, liver

\section{Tümörü taklit eden primer hepatik aktinomikoz (Inflamatuar Psödotümör): Olgu sunumu ve literatür derlemesi}

\section{ÖZET}

Aktinomikoz genellikle servikofasiyal bölgede abseler şeklinde ortaya çıkar. Karaciğer tutulumu çoğunlukla batın içi enfeksiyonlara ikincil olarak gelişir. "İzole veya Primer Hepatik Aktinomikoz (PHA)" başka bir enfeksiyon odağının gösterilemediği karaciğer yerleşimli aktinomikozu tanımlar. Burada, hepatik aktinomikozun karaciğerde saptanan kitle lezyonlarının ayıııı tanısında yer alması gerektiğini ve risk faktörü olmayan hastalarda da gelişebileceğini vurgulamayı amaçladık. Epigastrik hassasiyet, sağ üst kadran ağrııı, ateş, kilo kaybı yakınmalarıyla başvuran 24 yaşında erkek hasta, görüntülemede karaciğerde tümör-benzeri kitle saptanması nedeniyle hastanemize yatırıldı. Hastanın, Aktinomikoz için herhangi bir risk faktörü veya eşlik eden hastalığı yoktu. İngilizce tıp literatüründeki 1993-2014 yılları arasındaki tüm benzer PHA olgularını derledik. Aktinomikotik karaciğer psödotümörleri, hiçbir risk faktörü veya ek hastalığı olmayan hastalarda bile soliter karaciğer lezyonlarının ayıııı tanısında hatıllanmalıdır. Tanı ve tedavide multidisipliner yaklaşım çok önemlidir.

Anahtar kelimeler: Actinomycosis, Actinomyces spp, inflamatuvar psödotümör, karaciğer

\section{INTRODUCTION}

Actinomyces spp are Gram positive, anaerobic and filamentous bacilli, and are commensals of the oral cavity, gastrointestinal and genital tract. Actinomy- cosis is a chronic, slowly progressive, suppurative and granulomatous disease caused by Actinomyces israelii. ${ }^{1,2}$ It has been called "the most misdiagnosed disease" and the diagnosis may be missed even by

\footnotetext{
Correspondence: Ayse Batirel, Kartal Dr. Lutfi Kirdar Education and Research Hospital, Infectious Diseases and Clinical Microbiology, Semsi Denizer Cd. E-5 Karayolu Cevizli Mevkii 34890 Kartal, İstanbul, Turkey Email: aysebatirel@yahoo.com Received: 27.July.2014, Accepted: 09.October.2014 Copyright (C) Journal of Microbiology and Infectious Diseases 2015, All rights reserved
} 
experienced clinicians. Although its incidence has been diminishing, it is so often confused with a tumor. ${ }^{3}$ Infection occurs through mucosal disruption and invasion. Although most patients manifest with abscesses in the cervicofacial region, cases of thoracic, abdominal, pelvic and central nervous system actinomycosis have also been reported. The ileocecal region is the most frequently involved region in the abdomen. ${ }^{4,5}$ Hepatic actinomycosis is a rare disease with an overall mortality rate of $7.6 \% .{ }^{6}$ The symptoms and signs are similar to other pyogenic liver abscesses, but the course is more indolent in actinomycosis. ${ }^{7}$ Hepatic involvement which occurs usually secondary to intraabdominal infection has been reported in $15 \%$ of abdominal disease and in $5 \%$ of all cases of actinomycosis. ${ }^{8}$ If the source of the infection cannot be demonstrated, these cases are classified as isolated or primary hepatic actinomycosis (PHA). ${ }^{7,9}$ Sometimes hepatic lesions may mimic malignant lesions both clinically and radiologically and those lesions are referred as "inflammatory pseudo-tumor". ${ }^{7,8,10}$ In majority of the previously reported cases with actinomycosis, there is at least one predisposing condition or comorbidity. However, our patient was a young immunocompetent adult with no underlying risk factors or diseases. Therefore, by describing this case and reviewing similar cases, we aimed to highlight hepatic actinomycosis in the differential diagnosis of hepatic mass lesions, and also its occurrence even in patients without underlying risk factors or predisposition, in addition, to point out the importance of a multi-disciplinary approach in the differential diagnosis and management. Written informed consent for presentation of this case has been obtained from our patient.

\section{CASE REPORT}

A 25-year-old previously healthy man presented to our hospital because of anorexia, weight loss, abdominal distension, right upper quadrant abdominal pain and fever of a year's duration. Medical history was unremarkable. On examination, tenderness on the right upper quadrant of the abdomen of the patient and hepatomegaly $(8 \mathrm{~cm}$ under the costal margin) were noted on palpation. He had no dental carries or signs of periodontitis. Laboratory tests revealed elevated erythrocyte sedimentation rate (84 $\mathrm{mm} / \mathrm{h}$, normal $0-12 \mathrm{~mm} / \mathrm{h}$ ), C-reactive protein level (CRP) (122 mg/L, normal 0-3 mg/L), and anemia (hemoglobin $8.9 \mathrm{mg} / \mathrm{dl}$, hematocrit 29\%, normal 12 $16 \mathrm{mg} / \mathrm{dl}, 42-52 \%$, respectively). Liver transaminases were within normal limits. Abdominal ultrasound (US) revealed a hypoechoic mass $91 \times 71 \mathrm{~mm}$ in di- ameter with irregular borders in the left lobe of liver. On computed tomography (CT) scan, an isodense [denoting a tissue having a radiopacity (radiodensity) similar to that of another or adjacent tissue] lesion $85 \times 75 \mathrm{~mm}$ in diameter with a thick and irregular capsule, and invasion of the overlying ribs which had no contrast enhancement (Figure 1) was visualized. Tumor markers [Carcinoembryonic antigen (CEA), carbohydrate antigen (CA)19-9, CA 12-5, CA 15-3, alpha fetoprotein] were normal. Serologic tests for Hepatitis B and C viruses, Human immunodeficiency virus (HIV), Cytomegalovirus, Herpes Simplex Virus, Echinococcus granulosus and Entamoeba histolytica were all negative. Indirect hemagglutination test for hydatid cyst was also negative.

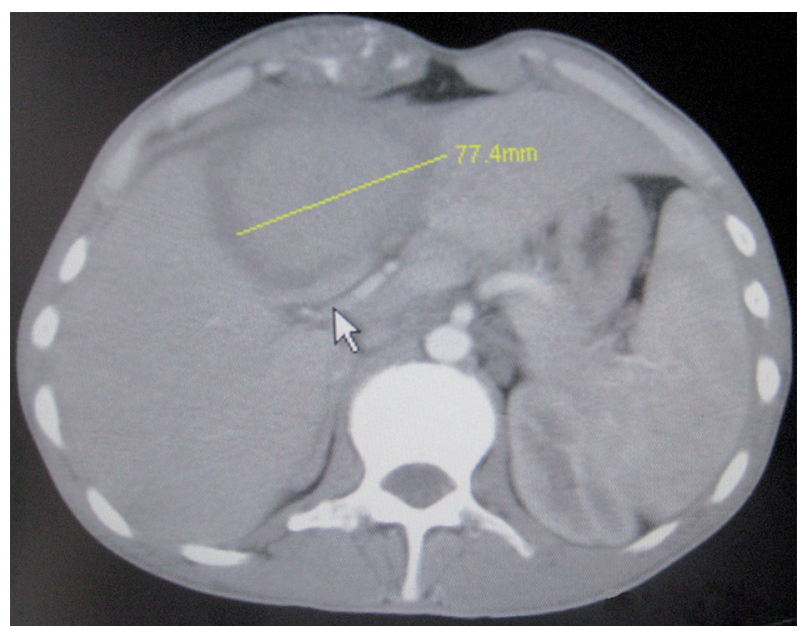

Figure 1. Computerized tomography image of the abdomen: An isodense lesion $85 \times 75 \mathrm{~mm}$ in diameter with a thick and irregular capsule, and invasion of the overlying ribs which had no contrast enhancement

Intravenous ceftriaxone $2 \times 1 \mathrm{~g}$ (1 gram every 12 h) and metronidazole $4 \times 500 \mathrm{mg}$ (500 milligrams every $6 \mathrm{~h}$ ) were initiated empirically. Blood and urine cultures were negative, however fever continued for 10 days after the initiation of antibiotic treatment. The patient underwent exploratory laparotomy which revealed a tumor-like mass $(10 \times 10 \mathrm{~cm}$ in diameter in liver segment 4, 5 and 6) infiltrating the duodenum, colon and the abdominal wall. Histopathologic examination of the core biopsy frozen section demonstrated degeneration in parenchymal cells, mild to moderate inflammatory cell infiltration in portal areas (Figure 2a, 2b, 2c).

Bacterial cultures remained sterile, possibly because of fastidious nature of growth and prior antibiotic therapy. Microscopic examination of PAS, 
Giemsa and Grocott's methenamine silver stained specimens revealed aggregates of branching filamentous microorganisms termed "sulfur granules" forming a granular structure in focal microabscesses (Figure 2a, 2b, 2c). These findings were compatible with actinomycosis which caused an inflammatory pseudotumor. Examination of the oral cavity, panoramic dental X-ray, upper and lower gastrointestinal endoscopy, colonoscopy, abdominal US, tho- racic and abdominal CT scans failed to demonstrate any other likely focus of infection or site of origin. Therefore, it was considered as a PHA. Ampicillinsulbactam $4 \times 1.5 \mathrm{~g}(1,5$ grams every $6 \mathrm{~h})$ iv for 2 weeks and then amoxicillin-clavulonate $2 \times 1 \mathrm{~g}$ po for the next 10 weeks were administered. A control abdominal USG of the patient after 12 weeks showed complete resolution of the previous hepatic lesion.
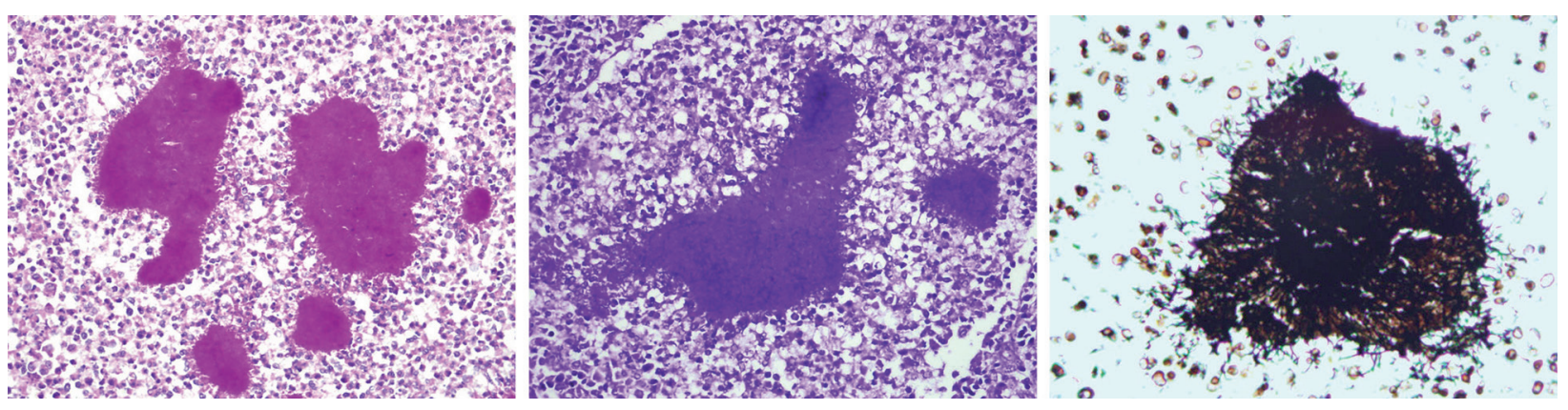

Figure 2a, 2b, 2c. Microscopic examination of PAS (2a), Giemsa (2b) and GROCOTT (2c) stained specimens revealed aggregates of branching filamentous microorganisms termed "sulfur granules" forming a granular structure in focal microabscesses. Inflammatory reaction and fibrosis with polymorphonuclear cells, lymphoplasmocytes, and histiocytes were visualized.

\section{DISCUSSION}

Actinomyces spp cause opportunistic infections more commonly. The anatomical distribution is $60 \%$ cervicofacial, $15 \%$ thoracic, $20 \%$ abdominal, and $5 \%$ other sites. ${ }^{11}$ Actinomyces spp produces proteolytic enzymes and can spread by direct invasion and extension without regard to tissue planes. ${ }^{12,13}$ Spread to the liver occurs via direct extension from a contiguous abdominal focus or hematogenously from a distant lesion via portal vein or hepatic artery. Hepatic lesions occasionally infiltrate the diaphragm and are complicated by pleural and lung lesions, can form cutaneous fistula and sinus tracts, and extend to the abdominal and pelvic organs. ${ }^{11}$ The tumor-like lesion in our case infiltrated to the abdominal wall and was attached to the colon and duodenum.

Hepatic actinomycosis usually occurs in males (70-97\% of cases) in the fourth and fifth decades. ${ }^{6,9,14}$ Risk factors include poor oral hygiene, previous dental procedures, perforated peptic ulcer, colonic diverticulitis, abdominal or pelvic surgery, abdominal wall trauma, gastrointestinal foreign body or lesions, gallstones, immunosupression, diabetes mellitus, inflamatory bowel disease such as ulcerative colitis, alcoholism, intravenous drug abuse, longstanding intra-uterine device in females. ${ }^{6,9,11,15,16}$
The most common predisposing event has been reported to be appendicitis. ${ }^{17}$ Our patient had no underlying risk factors. He had no history of blunt abdominal trauma or surgery. Also, no underlying cause of immunosuppression was detected. CD4, CD8 counts, serum IgG, IgA, IgM levels were normal. We reviewed the English language literature (pubmed, google scholar) for similar PHA cases with no underling risk factors or predisposition from 1993 to September 2014. We excluded the cases with comorbidity or predisposing risk factors for actinomycosis. We summarized the demographic, clinical, diagnostic and therapeutic features of the reviewed similar cases in Table 1., 1,2,6,9-17

In patients with hepatic actinomycosis, the presenting symptoms are often nonspecific. Fever, abdominal pain, and weight loss are common presenting complaints, with a subacute onset and a prolonged course. $8,9,18$ Symptoms are usually present for 1-6 months prior to the patient's presentation. ${ }^{9}$ Although most reported cases of hepatic actinomycosis had abnormal liver function tests, transaminases may be within normal limits and therefore misleading. ${ }^{8}$ Laboratory examination often demonstrates a leukocytosis $(75 \%)$ with a shift to the left and elevation of alkaline phosphatase $(83,3 \%){ }^{15}$ The CRP level also could be above normal. ${ }^{6,16}$ 


\begin{tabular}{|c|c|c|c|c|c|c|c|c|}
\hline & 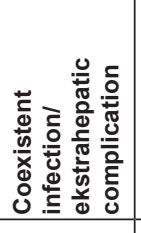 & 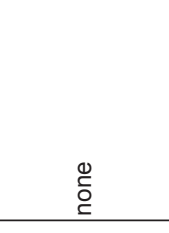 & \begin{tabular}{l}
0 \\
\multirow{\Sigma}{0}{} \\
\end{tabular} & 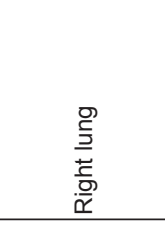 & 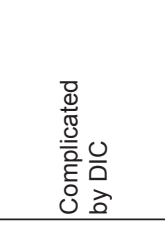 & 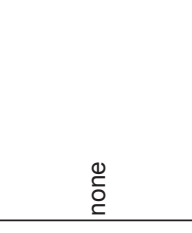 & \begin{tabular}{l}
0 \\
\multirow{2}{0}{} \\
\end{tabular} & 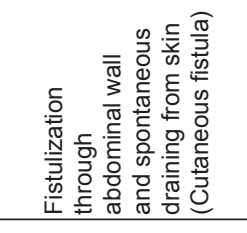 \\
\hline & 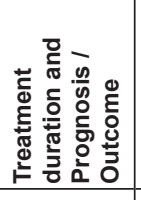 & 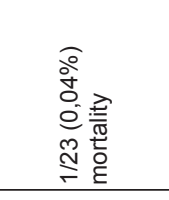 & $\overline{\overline{\mathbb{0}}}$ & 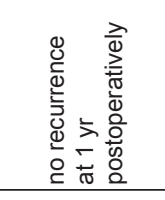 & 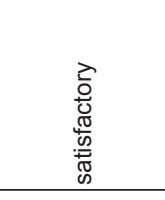 & 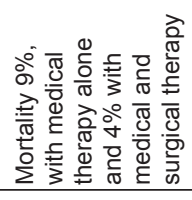 & & \\
\hline & 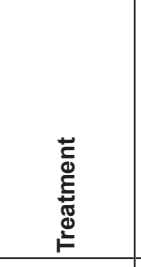 & 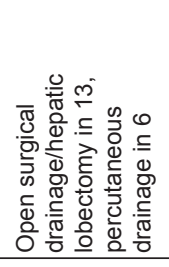 & 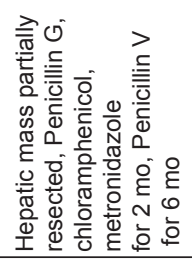 & 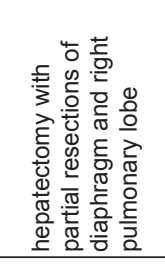 & 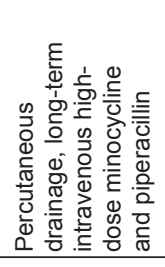 & & & 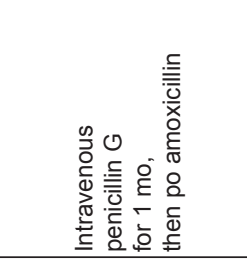 \\
\hline & 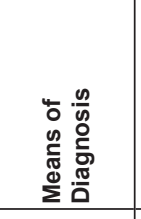 & 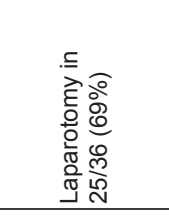 & $\begin{array}{l}5 \\
0 \\
5 \\
\end{array}$ & & & 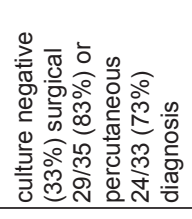 & 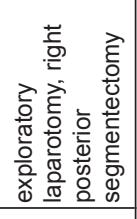 & 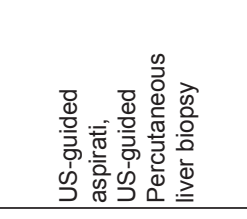 \\
\hline & 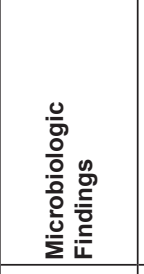 & 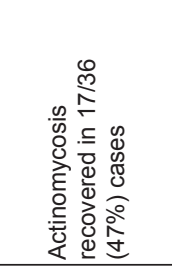 & 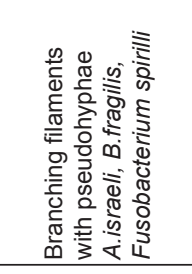 & 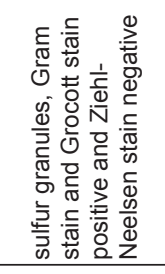 & 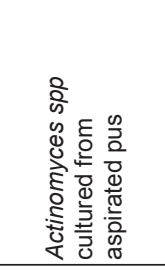 & 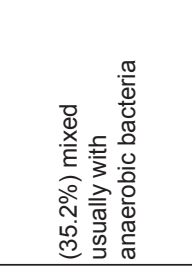 & & 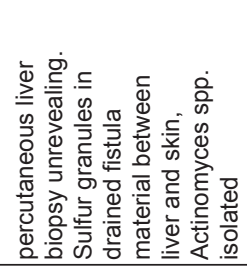 \\
\hline & 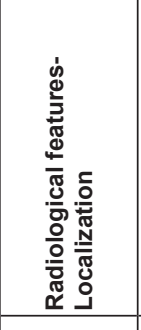 & 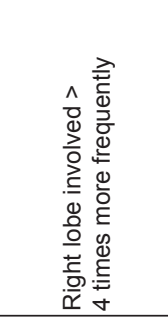 & 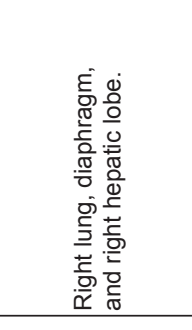 & 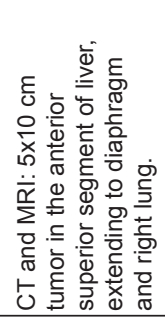 & 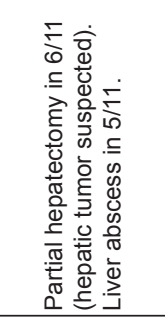 & 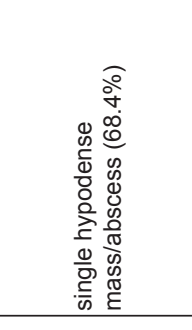 & 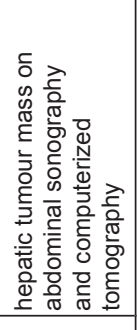 & 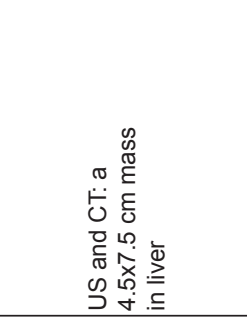 \\
\hline & 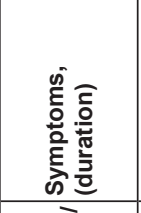 & 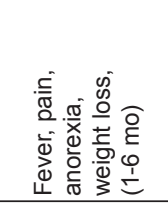 & $\begin{array}{c}\stackrel{\circ}{E} \\
m\end{array}$ & 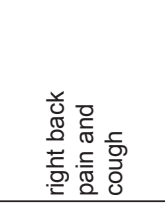 & & & & 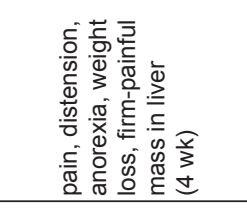 \\
\hline & 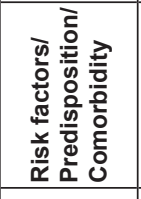 & 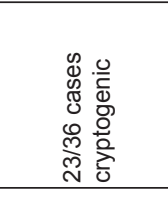 & 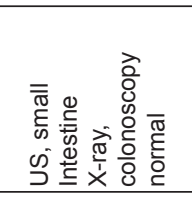 & & 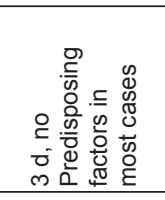 & 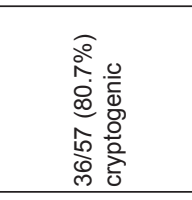 & 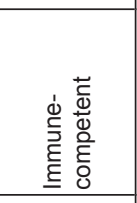 & $\begin{array}{l}\stackrel{0}{\circ} \\
\stackrel{0}{\circ}\end{array}$ \\
\hline & 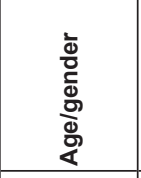 & 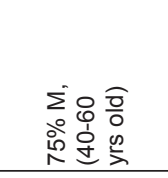 & 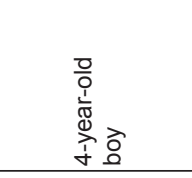 & $\begin{array}{l}\sum \\
\dot{\sigma}\end{array}$ & $\begin{array}{l}\sum \\
\infty \\
\infty \\
\infty\end{array}$ & 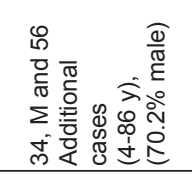 & $\sum_{\substack{n \\
[n}}$ & $\begin{array}{l}L \\
F\end{array}$ \\
\hline & 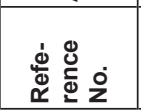 & 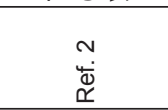 & 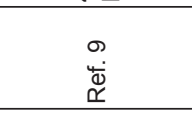 & 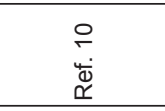 & 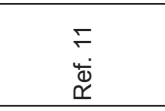 & 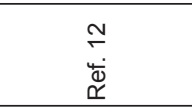 & 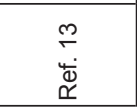 & 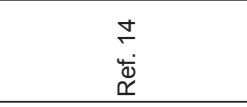 \\
\hline
\end{tabular}




\begin{tabular}{|c|c|c|c|c|c|}
\hline 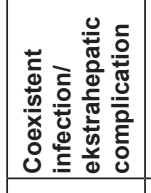 & 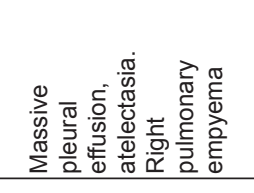 & 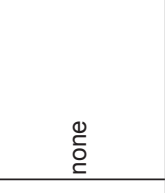 & 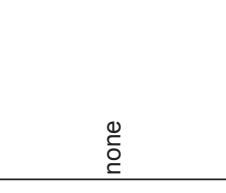 & $\begin{array}{l}0 \\
\text { ¿े } \\
\text { ¿̇ }\end{array}$ & 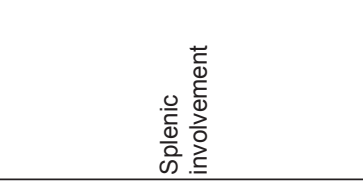 \\
\hline 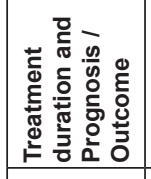 & $\begin{array}{l}\overline{8} \\
8 \\
\end{array}$ & 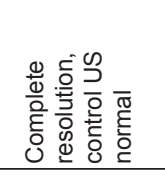 & 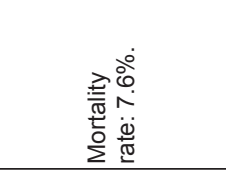 & 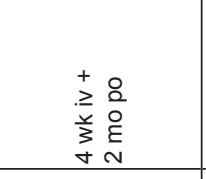 & 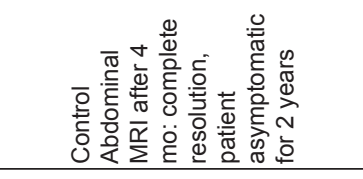 \\
\hline 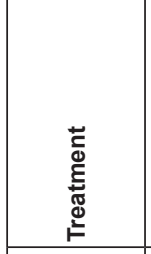 & 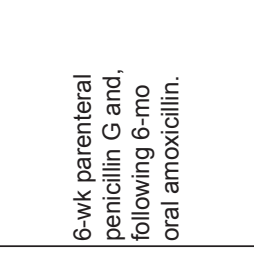 & 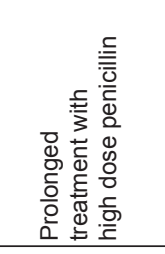 & 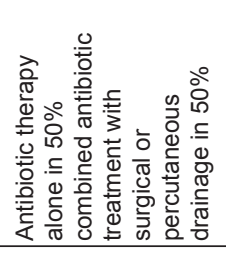 & 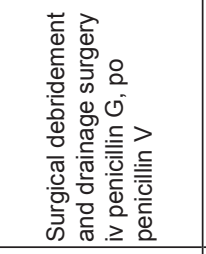 & 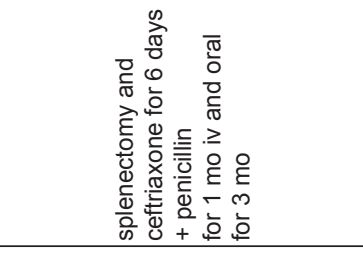 \\
\hline 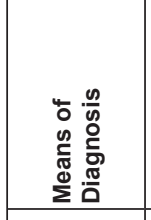 & 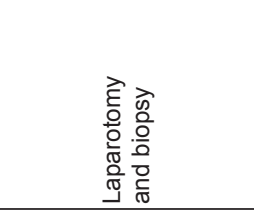 & 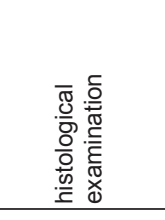 & 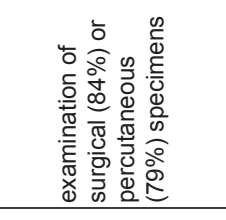 & 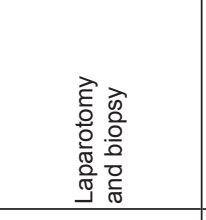 & 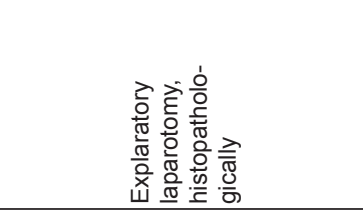 \\
\hline 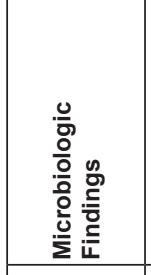 & 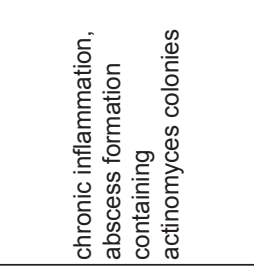 & & 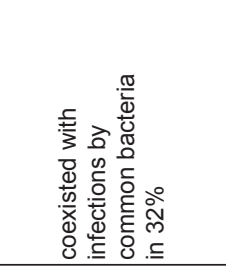 & 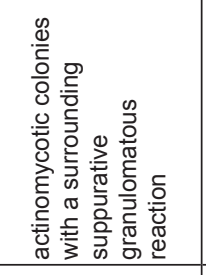 & 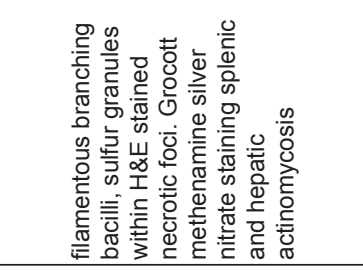 \\
\hline 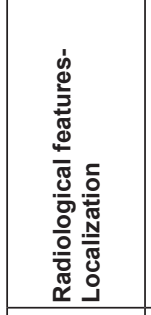 & 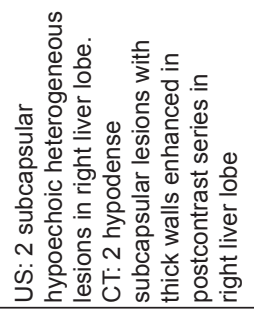 & 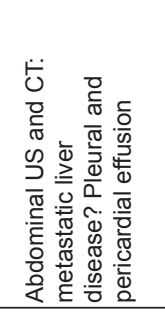 & 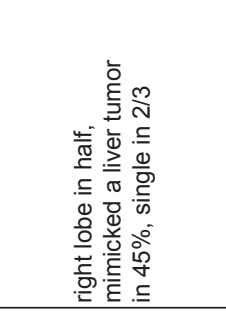 & 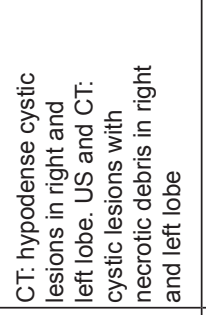 & 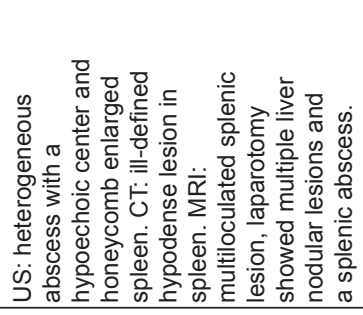 \\
\hline 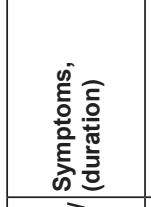 & $\underset{\infty}{\stackrel{\wp}{\xi}}$ & 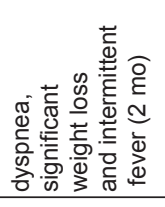 & & 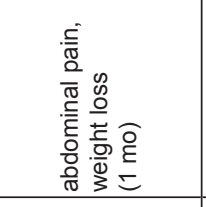 & 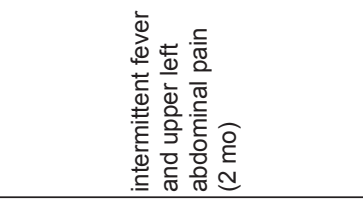 \\
\hline 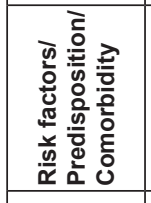 & 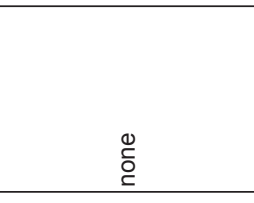 & 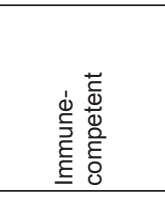 & 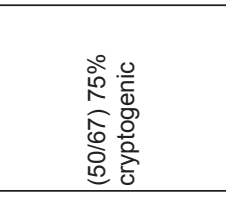 & 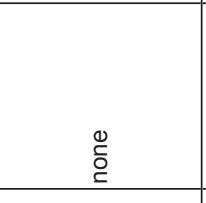 & 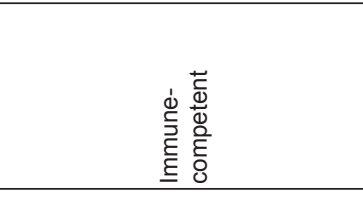 \\
\hline 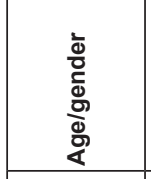 & $\begin{array}{l}u \\
\dot{\sigma} \\
\end{array}$ & $\begin{array}{l}4 \\
0 \\
0 \\
6\end{array}$ & 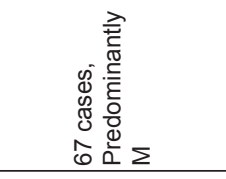 & $\begin{array}{l}\sum \\
\text { g } \\
\end{array}$ & $\begin{array}{l}\sum \\
\hat{m}\end{array}$ \\
\hline 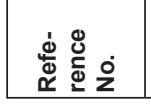 & 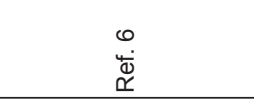 & 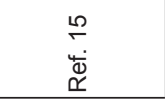 & 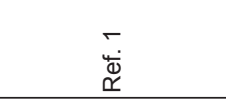 & 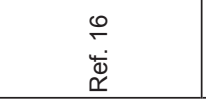 & 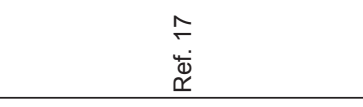 \\
\hline
\end{tabular}


A single hypodense mass, as in our case, is the most common radiological finding (observed in $2 / 3$ of the cases), but it may also cause multiple lesions. ${ }^{16,18}$ Lesions were most often described as single or multiple abscesses and soft central loculations containing white or yellow pus. As the differential diagnosis from malignant lesions could not be made with radiologic studies ${ }^{7}$, actinomycosis is often misdiagnosed as primary or metastatic liver tumor. ${ }^{6,15}$ Hepatic lesions mimicking malignant lesions both radiologically and clinically are called "inflammatory pseudo-tumor". Right liver lobe is four times more frequently affected then the left lobe. ${ }^{13}$ Infectious diseases in the differential diagnosis include pyogenic liver abscesses, amebiasis and echinococcosis.

Because of its fastidious nature, it is difficult to cultivate the microorganism and it may take up to two weeks to grow in culture media. Blood cultures grew the bacteria in $15.4 \%$ of the cases. In $82.9 \%$ of the patients, diagnostic specimen was obtained by surgical intervention. ${ }^{18}$ Gram staining and microscopy can reveal yellow clusters of filaments surrounded by neutrophils, known as "sulfur granules". Definitive diagnosis is based upon microscopic visualization of typical 'sulfur granules' (microcolonies of the organism) or recovery of Actinomyces organisms in anaerobic culture. The diagnosis also may be suggested by visualization of organisms with the characteristic branched, gram-positive, filamentous, and often beaded morphology. ${ }^{9,13}$ Nocardia species are indistinguishable from Actinomyces organisms by Gram stain but can be excluded by staining specimens with a modified acid-fast protocol. ${ }^{9} \mathrm{Be}-$ sides histopathological appearance, positive Gram staining and presence of sulfur granules were other findings in diagnosis of actinomycosis.

The treatment of isolated hepatic actinomycosis is managed by antibiotic treatment only in one half of the cases, surgical excision or percutaneous drainage in addition to antibiotic therapy may be necessary in the other half. .,9 $^{6}$ Actinomycosis species are generally susceptible to penicillin $\mathrm{G}$ and amoxicillin but resistant to ciprofloxacin. ${ }^{11}$ Tetracycline, erythromycin, doxycycline, clindamycin, rifampicin, chloramphenicol, ceftriaxone and imipenem are alternative agents for antimicrobial therapy. ${ }^{6,18} \mathrm{Com}-$ bined surgical excision /drainage and 12 weeks of antimicrobial therapy resulted in the recovery of the patient.

\section{CONCLUSION}

PHA is a rare disease among solitary liver masses and can mimick malignant tumors clinically and radiologically. Therefore, it should be considered in the differential diagnosis of space-occupying solitary liver lesions even in patients with no predisposing risk factor. Multi-disciplinary collaboration is important in the diagnosis and management.

\section{REFERENCES}

1. Burden P. Actinomycosis. J Infect 1989;19:95-99.

2. Cope Z. Actinomycosis involving the colon and the rectum. J Int Coll Surg 1949;12:401-404.

3. Weese WC, Smith IM. A study of 57 cases of actinomycosis over a 36-year period. A diagnostic 'failure' with good prognosis after treatment. Arch Intern Med 1975;135:1562-1568.

4. Cintron JR, Del Pino A, Duarte B, Wood D. Abdominal actinomycosis. Dis Colon Rectum 1996;39:105-108

5. Piper MH, Schaberg DR, Ross JM, et al. Endoscopic detection and therapy of colonic actinomycosis. Am J Gastroenterol 1992;87:1040-1042.

6. Kanellopoulou T, Alexopoulou A, Tanouli MI, et al. Primary hepatic actinomycosis. Am J Med Sci 2010;339:362-365.

7. Tamsel S, Demirpolat G, Killi R, Elmas N. [Primary hepatic actinomycosis: a case of inflammatory pseudotumor (case report)]. Tani Girisim Radyol 2004;10:154-157.

8. Wong JJ, Kinney TB, Miller FJ, Rivera-Sanfeliz G. Hepatic actinomycotic abscesses: diagnosis and management. AJR Am J Roentgenol 2006;186:174-176.

9. Miyamoto MI, Fang FC. Pyogenic liver abscess involving Actinomyces: case report and review. Clin Infect Dis 1993;16:303-309.

10. Lai AT, Lam CM, Ng KK, et al. Hepatic actinomycosis presenting as a liver tumour: case report and literature review. Asian J Surg 2004;27:345-347.

11. Uehara Y, Takahashi T, Yagoshi M, et al. Liver abscess of Actinomyces israelii in a hemodialysis patient: case report and review of the literature. Intern Med 2010;49:2017-2020.

12. Sheth S, Fishman EK, Sanders R. Actinomycosis involving the liver. Computed tomography/ultrasound correlation. J UItrasound Med 1987;6:329-331.

13. Kocabay G, Cagatay A, Eraksoy H, et al. A case of isolated hepatic actinomycosis causing right pulmonary empyema Chin Med J (Engl) 2006;119:1133-1135.

14. Putman HC, Jr., Dockerty MB, Waugh JM. Abdominal actinomycosis; an analysis of 122 cases. Surgery 1950;28:781800.

15. Lall T, Shehab TM, Valenstein P. Isolated hepatic actinomycosis: a case report. J Med Case Rep 2010;4:45.

16. Islam $\mathrm{T}$, Athar MN, Athar MK, et al. Hepatic actinomycosis with infiltration of the diaphragm and right lung: a case report. Can Respir J 2005;12:336-337.

17. Deshmukh N, Heaney SJ. Actinomycosis at multiple colonic sites. Am J Gastroenterol 1986;81:1212-1214.

18. Sharma M, Briski LE, Khatib R. Hepatic actinomycosis: an overview of salient features and outcome of therapy. Scand $\mathrm{J}$ Infect Dis 2002;34:386-391. 